\title{
Penerapan pendekatan metakognitif terhadap self-efficacy siswa SMP ditinjau dari kemampuan awal siswa
}

\author{
Asep Ikin Sugandi, Siti Chotimah \\ Prodi Pendidikan Matematika Fakultas Pendidikan Matematika dan Sains, \\ IKIP Siliwangi, Jl. Terusan Jenderal Sudirman Kebon Rumput Cimahi \\ asepikinsugandi@ikipsiliwangi.ac.id
}

Received: 18 Mei 2020; Accepted: 28 Juni 2020 ; Published: 29 Desember 2020

\begin{abstract}
Abstrak
Penelitian ini bertujuan untuk menelaah efektivitas pendekatan metakognitif dalam meningkatkan selfefficacy siswa smp. Populasi dalam penelitian ini adalah seluruh siswa disalah satu smp di Kota Cimahi, sedangkan sampelnya dipilih dua kelas dari dari smp terpilih. Instrumen dalam penelitian ini berupa non tes berbentuk skala Likert. Berdasarkan hasil pengolahan data didapatkan kesimpulan bahwa self-efficacy siswa yang belajar dengan pendekatan metakognitif lebih baik daripada dengan pendekatan saintifik dan tidak terdapat interaksi antara pendekatan dengan tingkat kemampuan awal siswa terhadap self-efficacy.
\end{abstract}

Kata kunci: Metakognitif, Self-Efficacy, Kemampuan Awal Siswa

\begin{abstract}
This study aims to examine the effectiveness of the metacognitive approach in improving the self-efficacy of junior high school students. The population in this study were all students of junior high school in the city of Cimahi, while the sample was two classes from chosen junior high school. The instrument in this research was a non-test of a Likert scale. Based on the results of data processing, it can be concluded that the selfefficacy of students taught by the metacognitive approach is better than the scientific approach and there is no interaction between the approach and the initial level of students' ability towards self-efficacy.
\end{abstract}

Keywords: Metacognitive, Self-Efficacy, Students' Early Ability 


\section{PENDAHULUAN}

Self-efficacy merupakan satu aspek afektif dimana setiap siswa yang mempelajari matematika harus memiliki dan mengembangkannya. Hal ini sejalan dengan tujuan pembelajaran KTSP 2006 dan kurikulum 2013 yang menuntut perubahan dalam cara berpikir serta berperilaku dalam semua pembelajaran termasuk matematika. Tujuan kurikulum tersebut dalam berbagai kemampuan matematis dan dalam aspek afektif antara lain: memiliki sifat personal yang dapat menghargai kegunaan matematika dalam aktivitas sehari-hari, ketertarikan dan minat dalam mempelajari matematika, rasa ingin mengtahui, pun juga gigih dan percaya diri dalam proses memecahkan masalah (Hendriana, Rohaeti, \& Sumarmo, 2017).

Self-efficacy merupakan keyakinan siswa terhadap kemampuan dirinya dalam kegiatan belajar matematika misalnya dalam menghadapi suatu masalah matematika yang terlihat sulit. Self-efficacy yang semakin meningkat pada diri siswa mengakibatkan bertambah baik juga aktivitas yang dilaksanakan untuk menyelesaikan berbagai macam tugas dan tanggungjawabnya (Herawaty, 2013). Siswa yang memiliki tingkat yang rendah dalam self-efficacy biasanya menjauhi pelajaran yang memberikan tugastugas yang menantang. Sedangkan, siswa yang memiliki self-efficacy tinggi memiliki hasrat yang besar untuk menyelesaikan tugastugasnya (Aisyah, 2008). Fitri (2017) mengatakan Ada empat prinsip self-efficacy, yaitu: (1) Self-efficacy mampu meningkatkan pencapaian pribadi; (2) Jika melihat orang lain berhasil atau gagal dalam menjalankan tugas tertentu, self-efficacy akan menurun ataupun meningkat. (3) Jika Anda mendorong seseorang untuk melakukan sesuatu, efikasi diri akan meningkat, tetapi jika Anda gagal, efikasi diri akan hilang; (4) Tekanan emosional yang terkait dengan efikasi diri berhubungan dengan. Bandura (1997) menerangkan indikator self-efficacy terdiri dari (1) pengalaman keberhasilan dan kegagalan diri sendiri (performance experience) (2) pengalaman keberhasilan dan kegagalan orang lain (3) aspek pendukung langsung/sosial (verbal persuasion) (4) kondisi psikologi. Pengalaman personal menjadi hal yang digantungi oleh tingkat selfefficacy, pengetahuan yang dipelajari dari pengalaman orang lain, pendapat positif atau negatif orang lain tentang kinerja pribadinya, dan perilaku emosional yang baik atau buruk (Setiadi, 2010).

Hasil penelitian Juhrani, Suyitno, \& Khumaedi (2017) menyimpulkan bahwa siswa yang memiliki self-efficacy sedang dan rendah belum bisa mengeluarkan ide-ide matematis secara maksimal. Serupa dengan itu, Adni, D.N., Nurfauziah, P., \& Rohaeti, E.E. (2018) mengungkapkan bahwa rata-rata siswa takut salah dan tidak yakin dalam menyelesaikan masalah yang diberikan. Sedangkan, Alifia, N.N. dan Rakhmawati, I.A. (2018) juga mengungkapkan bahwa jika siswa menemukan sesuatu yang dia kurang pahami maka akan cenderung diam dan tidak bertanya. Berdasarkan hasil observasi peneliti dan wawancara dengan guru matematika SMP Negeri di kota Cimahi ditemukan bahwa siswa memiliki self-efficacy yang rendah dalam matematika. Guru sudah berusaha memberikan tugas berupa soal yang berbeda kepada siswa, namun upaya tersebut belum mampu menaikkan tingkat self-efficacy siswa. Hal ini dapar dilihat dari banyaknya siswa yang masih menyelesaikan PR disekolah dan melihat jawaban PR temannya. Dalam ujian, sebagian besar siswa yang melihat jawaban temannya yang dianggap lebih cerdas. Hal ini memperlihatkan bahwa siswa tersebut lebih percaya diri dengan jawaban yang didapat dari temannya. 
Penerapan pendekatan metakognitif terhadap self-efficacy siswa SMP ditinjau dari kemampuan awal siswa

Selain itu siswa masih ragu menjawab soal yang ditanyakan langsung kepada siswa, mereka tidak yakin jawabannya. Banyak pula mahasiswa yang tidak yakin dengan kemampuannya, hal ditunjukkan dengan sikap mahasiswa tidak berusaha menyelesaikan masalah, mengurangi keseriusan dalam mengikuti perkuliahan, cepat menyerah, mudah merasa puas dengan hal yang t`elah dicapai (Warsito, 2012). Dari hasil penelitian dan observasi dapat dismpulkan bahwa selfefficacy siswa masih perlu ditingkatkan.

Menentukan metode pembelajaran yang sesuai dengan tujuan tersebut merupakan tuntutan bagi guru agar dapat meningkatkan dan mengembangkan self-efficacy. Salah satu cara untuk meningkatkan self-efficacy siswa adalah pendekatan metakognitif. Nindiasari, Kusumah, Sumarmo, \& Sabandar (2014) mengemukakan bahwa pendekatan metakognitif adalah pendekatan yang menekankan pada proses menyadarkan siswa untuk mengontrol, mengakses proses berpikirnya sendiri serta mendorong mereka untuk memahami dan menemukan konsep, berkomunikasi disertai dengan alasan yang relevan serta menghubungkan pengetahuan baru dengan pengetahuan yang diperoleh sebelumnya dan merefleksi proses dan hasil pembelajaran. Kemudian Aminah, Kusuma, Suryadi, \& Sumarmo (2018) mengelaborasi beberapa langkah pembelajaran metakognitif sebagai berikut: memodelkan; metacognitive scaffolding; diskusi berpasangan, kelompok kecil, atau diskusi kelas; dan menyusun jurnal metakognitif. Melalui kegiatan-kegiatan tersebut siswa didorong untuk menumbuhkan self-efficacy.

Sudah banyak hasil penelitian metkognitif ini diantaranya Noordyana (2016), Mawaddah \& Suyitno (2015), Nindiasari et al. (2014) melaporkan keunggulan pembelajaran metakognitif daripada pembelajaran biasa dalam meningkatkan beragam kemampuan matematik dan segi afektif siswa SMP dan SMA. Serupa dengan temuan yang sudah diuraikan, beberapa studi Jumroh, Mulbasari, \& Fitriasari (2018), Sukoco \& Mahmudi, (2016), R. I. Putri \& Santosa (2015), dengan subyek siswa SMP dan SMA dengan menerapkan berbagai pendekatan pembelajaran melaporkan pencapaian selfefficacy akan lebih baik jika pembelajaran disampaikan dengan pendekatan yang inovatif dibandingkan pendekatan biasa.

Berkenaan dengan Kemampuan Awal Matematik (KAM) studi (Armiati, 2011), menemukan bahwa KAM memberikan peran yang baik dalam mengembangkan beragam afektif siswa. Studi di atas melaporkan bahwa makin tinggi KAM siswa ditemukan juga siswa mencapai segi afektif yang makin tinggi pula. Temuan ini sejalan dengan makna hakekat matematika yang berposisi sebagai ilmu sistematik dan terstruktur, sehingga kemampuan awal matematik mendukung terwujudnya aspek emosional yang lebih baik.

Berdasarkan penjelasan yang telah diuraikan, peneliti menentukan tujuan dari penelitian yaitu agar dapat menelaah (1) self-efficacy matematika siswa yang memanfaatkan keguanaan pendekatan metakognitif dalam pembelajaran dan meninjaunya secara utuh dengan metode biasa, dan Tingkat Kemampuan Awal Siswa; (2) hubungan antara pendekatan pembelajaran metakognitif dengan kemampuan awal siswa terhadap self-efficacy.

\section{METODE}

Dalam studi ini, penelitian kuasi eksperimen merupakan metode yang peneliti gunakan, dimana kelas eksperimen menggunakan metode metakognitif untuk pembelajaran. Siswa SMP Negeri di Kota Cimahi secara keseluruhan dipilih peneliti sebagai populasi 
sedangkan sampelnya dipilih secara acak dengan menggunakan teknik random sampling yaitu dua kelas dari kelas VII pada salah satu SMP Negeri di kota Cimahi. Jumlah sampel dari dua kelas tersebut berjumlah 81 orang. Sesudah perlakuan kedua kelas diberi pos skala. Adapun desain penelitiannya sebagai berikut :

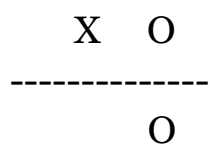

Keterangan :

$\mathrm{X}$ : Perlakuan berupa pemberian pendekatan metakognitif dalam pembelajaran

O : Pos skala

----- : Pemilihan sampel dengan cara random kelas

Dalam studi ini rupa dari instrumennya yaitu non tes dengan bentuk skala sikap Likert yang terdiri dari 25 pernyataan dengan dengan 4 opsi pilihan jawaban sebagai berikut: SS untuk sangat setuju, S untuk setuju, TS untuk tidak setuju, dan ST untuk sangat tidak setuju. Validitas yang diperlukan pada studi ini yaitu validitas konstruk dan validitas isi. Validitas isi dilakukan dengan mencari pendapat dari dua orang ahli.

Setelah instrumen divalidasi oleh dua orang para ahli, maka selanjutnya instrumen tersebut diujicobakan untuk mendapatkan validitas, reliabilitas dari soal tersebut. Dari hasil pengolahan data didapat validitas soal angket nilai $t$ hitung berkisar antara 2,65-8,63 sedangkan $t$ tabel sebesar 1,70 berarti t hitung lebih besar dari t tabel, sehingga semua butir angket dikatakan valid dan reliabilitasnya sebesar 0,93, berdasarkan Guilford (Ruseffendi, 2010) skala habits of minds berada pada kategori sangat tinggi.

Prosedur penelitian ini adalah sebagai berikut : (a) tahap persiapan meliputi: menentukan dua kelas sebagai sampel penelitian, dimana satu kelas dijadikan kelas eksperimen yang pembelajarannya menggunakan metakognitif dan satu kelas lain adalah kelas kontrol yang diberikan pendekatan saintifik, kemudian membuat rencana pembelajaran, lembar kerja siswa dan angket self-efficacy (b) Tahap pelaksanaan, pada tahapan ini peneliti menyampaikan pembelajaran pada kedua kelas sesuai dengan pendekatan masing-masing, dan pembelajaran dilakukan 9 pertemuan (c) tahap evaluasi dan pengolahan data, tahap ini meliputi memberikan skala sikap kepada siswa setelah pembelajaran selesai, mengolah data dan menganalisis data, kemudian membuat kesimpulan.

Uji normalitas tingkat kemampuan awal siswa dan pendekatan pembelajaran, menentukan homogenitas varians dan selanjutnya menggunakan anova dua arah, dan untuk menghitung presentasi skor habits of mind secara keseluruhan ditinjau sesuai dengan masing-masing indicator merupakan dasar dari pengolahan data.

Berikut merupakan kategori sikap yang dignunakan menurut Riduwan (2010).

Tabel 1. Kategori Presentase Skala Sikap

\begin{tabular}{cc}
\hline Nilai & Kriteria \\
\hline $0-30$ & sangat lemah \\
$31-50$ & lemah \\
$51-70$ & cukup \\
$71-85$ & kuat \\
\hline
\end{tabular}

\section{HASIL DAN PEMBAHASAN}

Setelah peneliti memberikan pembelajaran pada kedua kelas sesuai pendekatan masingmasing kelas dengan total 9 pertemuan maka dapat tahap pelaksanaan telah selesai dilakukan. Setelahnya skala sikap pun diberikan dan didapat hasil self-efficacy pada Tabel 2 berikut. 
Penerapan pendekatan metakognitif terhadap self-efficacy siswa SMP ditinjau dari kemampuan awal siswa

Tabel 2. Rangkuman Hasil Self-Efficacy Berdasarkan Tingkat Kemampuan Awal Siswa

\begin{tabular}{cccccccccc}
\hline & \multicolumn{3}{c}{ Pendekatan Metakognitif } & \multicolumn{3}{c}{ Pendekatan Saintifik } & \multicolumn{3}{c}{ Jumlah } \\
\cline { 2 - 10 } TKAS & $\overline{\boldsymbol{x}}$ & $\mathbf{S}$ & $\mathrm{n}$ & $\overline{\boldsymbol{x}}$ & $\mathbf{S}$ & $\mathrm{n}$ & $\overline{\boldsymbol{x}}$ & $\mathbf{S}$ & $\mathrm{N}$ \\
\hline Tinggi & 82,43 & 4,57 & 14 & 78,00 & 2,65 & 3 & 81,65 & 4,57 & 17 \\
Sedang & 72,71 & 3,29 & 24 & 66,65 & 3,40 & 37 & 69,03 & 4,47 & 61 \\
Rendah & 60,00 & 1,41 & 2 & 56,00 & $\mathbf{0}$ & $\mathbf{1}$ & 58,67 & 2,52 & 3 \\
Jumlah & 75,48 & 6,91 & 40 & 67,22 & 4,79 & 41 & 71,30 & 7,21 & 81 \\
\hline
\end{tabular}

Skor maksimum ideal : 100

Dari Tabel 2 didapat bahwa secara keseluruhan rata-rata self-efficacy siswa sebesar 71,30 (SMI 100). Hal ini dapat dikategorikan self-efficacy berada pada kategori sedang. Berdasarkan pendekatan pembelajaran didapat rata-rata self-eficacy siswa yang pembelajarannya menggunakan pendekatan metakognitif dan pendekatan saintifik berturut-turut 75,48 dan 67,22; simpangan bakunya 6,91 dan 4,79. Sehingga dapat disimpulkan self-efficacy siswa yang diajari dengan memanfaatkan kegunaan dari pendekatan metakognitif lebih baik dibandingkan pendekatan saintifik. Selain itu berdasarkan tingkat kemampuan awal siswa (TKAS) didapat rata-rata siswa dengan TKAS tinggi, sedang, dan rendah berturut-turut 81,$65 ; 69,03$ dan 58,67, simpangan bakunya
4,57; 4,47 dan 2,52. Hal ini menunjukkan bahwa self-efficacy siswa dengan TKAS tinggi lebih baik dibandingkan dengan TKAS rendahsedang, dan self-efficacy siswa dengan TKAS sedang lebih baik dibandingkan dengan TKAS rendah.

Selanjutnya dilakukan analisis statistika inferensial dengan menggunakan analisis varians dua jalur, namun sebelumnya akan diuji dahulu normalitas dan homogenies dua varians. Untuk menguji normalitas digunakan uji Shapiro-Wilk, dari hasil perhitungan didapat hasil seperti pada Tabel 3 sebagai berikut

Tabel 3. Hasil Uji Normalitas Berdasarkan Pendekatan Pembelajaran

\begin{tabular}{ccccc}
\hline Kelas & Statistik & Dk & Signifikasi & Keterangan \\
\hline Metakognitif & 0,98 & 40 & 0,56 & Ho diterima \\
Biasa & 0,95 & 41 & 0,064 & Ho diterima \\
\hline
\end{tabular}

Berdasarkan Tabel 3 didapat nilai signifikasi yang diperoleh untuk kelas yang menggunakan pendekatan metakognitif sebesar 0,56 dan nilai signifikasi yang diperoleh untuk kelas yang menggunakan pendekatan saintifik sebesar 0,064, karena kedua nilai signifikasi lebih besar dari pada 0,05, maka disimpulkan bahwa data kelas eksperimen maupun kelas kontrol berdistribusi normal. Selanjutnya akan diuji normalitas dengan dasar tingkat kemampuan awal siswa yang hasilnya diperlihatkan pada Tabel 4 berikut.

Tabel 4. Hasil Uji Normalitas Berdasarkan Tingkat Kemampuan Awal Siswa (TKAS)

\begin{tabular}{ccccc}
\hline TKAS & Statistik & dk & Signifikasi & Kesimpulan \\
\hline Tinggi & 0,93 & 17 & 0,21 & Ho diterima \\
Sedang & 0,98 & 61 & 0,24 & Ho diterima \\
Rendah & 0,00 & 3 & 0,78 & Ho diterima \\
\hline
\end{tabular}

Berdasarkan hasil uji normalitas pada Tabel 4 diperoleh nilai signifikansi TKAS rendah, sedang, dan tinggi secara berturut-turut yaitu sebesar 0,78; 0,24; 0,21; dan yang mana nilai signifikansi tersebut lebih besar dari 0,05.
Artinya, data TKAS tinggi, sedang, dan rendah berdistribusi normal. Setelah diketahui data berdistribusi normal maka dilakukan uji selanjutnya yaitu uji homogenitas, hasil uji homogenitas disajikan pada Tabel 5 .

Tabel 5. Hasil Uji Homogenitas Varians

\begin{tabular}{cccccc}
\hline Lavene Statistik & dk1 & & dk2 & Signifikasi & Kesimpulan \\
\hline 3,44 & 1 & 79 & 0,067 & Ho diterima \\
\hline
\end{tabular}


Berdasarkan Tabel 5, dengan nilai signifikansi yang lebih besar dari 0,05 yaitu 0,067 maka kedua varians pada penelitian ini homogen. Berdasarkan hasil analisis data pada Tabel 3, Tabel 4 dan Tabel 5, bisa ditarik kesimpulan bahwa data efikasi diri berdistribusi normal dan homogen. Untuk pengujian hipotesis selanjutnya akan digunakan pengujian ANOVA dua arah. Hasil uji ANOVA dua arah diberikan pada Tabel 6 berikut.

Tabel 6. Rangkuman Analisis Variansi Dua Jalur

\begin{tabular}{ccccccc}
\hline & JK & dK & RK & F & Signifikasi & Keterangan \\
\hline KELAS (A) & 106.367 & 1 & 106.367 & 8.373 & 0.005 & Ho ditolak \\
TKAS (B) & 1385.428 & 2 & 692.714 & 54.526 & 0.000 & Ho ditolak \\
KELAS *TKAS & 7.752 & 2 & 3.876 & .305 & 0.738 & Ho diterima \\
\hline
\end{tabular}

Berdasarkan hasil yang disajikan pada Tabel 6 didapat beberapa hasil seperti berikut ini.

(1) Mengenai pendekatan pembelajaran terhadap self efficacy. Hipotesis yang hendak diujikan sebagai berikut :

$\mathrm{H}_{\mathrm{o}}: \mu_{1}=\mu_{2}$ Tidak terdapat perbedaan self-efficacy matematis siswa yang diajar dengan pendekatan metakognitif dan pendekatan biasa.

$\mathrm{H}_{1}: \mu_{1}>\mu_{2}$ Self-efficacy matematis siswa yang diajari dengan memanfaatkan kegunaan dari pendekatan metakognitif lebih baik dibandingkan yang diajarkan dengan pendekatan biasa.

Berdasarkan hasil perhitungan pada Tabel 6 diektahui signifikansinya adalah 0,005 (2tailed), dan dihitung sebagai 1 tailed, sehingga menurut (Uyanto, 2009) signifikansinya adalah 0,005 / $2=0,0025$, karena nilai signifikannya kurang dari o,05 sehingga dapat ditarik kesimpulan. Self-efficacy matematis yang diajarkan kepada siswa dengan metode metakognitif lebih baik daripada metode saintifik.

(2) Mengenai hubungan di antara pendekatan pembelajaran menggunakan TKAS terhadap self-efficacy. Hipotesis yang hendak diujikan dalam penelitian ini yaitu: $\mathrm{H}_{\mathrm{o}}$ : tidak terdapat hubungan antara pendekatan pembelajaran dan TKAS terhadap self-efficacy siswa.

$\mathrm{H}_{1}$ : terdapat hubungan antara pendekatan pembelajaran dan TKAS terhadap selfefficacy siswa.

Berdasarkan hasil perhitungan yang disajikan Tabel 6 pada baris Kelas *TKAS diperoleh nilai signifikasi sebesar 0,738, yang lebih besar dari 0,05 sehingga dapat disimpulkan bahwa tidak terdapat hubungan antara pendekatan pembelajaran dan TKAS terhadap self-efficacy siswa.

(3) Tentang tingkat kemampuan awal siswa (TKAS). Hipotesis yang akan diuji adalah sebagai berikut:

$$
\begin{array}{ll}
\mathrm{H}_{0} \quad: \quad \mu_{1}=\mu_{2}=\mu_{3} \\
\mathrm{H}_{1} \quad \text { : } \quad \text { setidaknya terdapat satu pasang } \\
\\
\quad \text { yang berbeda. }
\end{array}
$$

Berdasarkan hasil yang disajikan Tabel 6 pada baris TKAS (B) diketahui nilai signifikasi sebesar 0,00, nilai signifikasi ini lebih kecil dari 0,05 maka dapat disimpulkan terdapat paling sedikit satu pasang yang tak sama. Untuk memperlihatkan TKAS mana yang lebih baik kemudian dilakukan uji lanjutan yang disebut uji Scheffe, hasil uji Scheffe ditampilkan pada Tabel 7 berikut. 
Penerapan pendekatan metakognitif terhadap self-efficacy siswa SMP ditinjau dari kemampuan awal siswa

Tabel 7. Rangkuman Uji Schffe

\begin{tabular}{ccccc}
\hline TKAS I & TKAS II & Selisih Rata-rata & Signifikasi & Keterangan \\
\hline Tinggi & Sedang & 10,536 & o,ooo & Ho ditolak \\
Tinggi & Rendah & 22,214 & o,ooo & Ho ditolak \\
Sedang & Rendah & 10,37 & o,ooo & Ho ditolak \\
\hline
\end{tabular}

Berdasarkan hasil perhitungan yang disajikan dalam Tabel 7 didapat nilai signifikasi berturut-turut sebagai berikut: o,oo; o,oo dan o,oo, karena nilai signifikasi tiap pasangan TKAS lebih kecil daripada 0,05, maka dapat dismpulkan bahwa self-efficacy siswa dengan TKAS rendah, demikian pula siswa dengan TKAS sedang memiliki self-efficacy lebih baik dari pada yang TKAS nya rendah. Selanjutnya akan dianalisis secara kualitatif perbedaan selfefficacy siswa yang pada proses pembelajarannya memanfaatkan kegunaan dari pendekatan metakognitif degan yang menggunakkan pendekatan saintifik.

Hasil pengolahan data terhadap self-efficacy siswa secara kualitatif diperlihatkan pada Tabel 8 berikut.

Tabel 8. Persentase Indikator Self-Efficacy Siswa

\begin{tabular}{|c|c|c|c|c|c|}
\hline \multirow[b]{2}{*}{ No. } & \multirow[b]{2}{*}{ Indikator } & \multicolumn{2}{|c|}{ Pendekatan Matakognitif } & \multicolumn{2}{|c|}{ Pendekatan Biasa } \\
\hline & & Presentase & Kriteria & Presentase & Kriteria \\
\hline 1. & Mastery Experience & 74 & Kuat & 60 & Cukup \\
\hline 2. & Vicarious Experience & 100 & Sangat Kuat & 64 & Cukup \\
\hline 3. & Physiological and & & & & \\
\hline & Affective State & 74 & Kuat & 68 & Cukup \\
\hline 4. & Verbal Persuasion & 83 & Sangat Kuat & 69 & Cukup \\
\hline & Jumlah & 75,47 & Kuat & 64,56 & Cukup \\
\hline
\end{tabular}

Berdasarkan pada Tabel 8 secara keseluruhan presentase self-efficacy siswa yang diajarkan memakai pendekatan metakognitif sebesar $75,47 \%$ dan berada pada kriteria kuat sedangkan presentase self-efficacy siswa yang diajarkan memakai pendekatan saintifik sebesar 64,56\% dan berada pada kriteria cukup, sehingga dapat dikatakan bahwa selfefficacy siswa yang diajarkan memakai pendekatan metakognitif lebih baik dibandingkan dengan yang diajarkan pendekatan saintifik. Indikator self-efficacy yang mendapat presentase tertinggi pada kelas eksperimen adalah indikator Vicarious Experience sedangkan indikator tertinggi pada kelas kontrol terletak pada indikator Verbal Persuasion. Berdasarkan presentase tiap indikator pada self-efficacy pada kelas eksperimen lebih tinggi dari pada presentase pada kelas control. Hal ini menuunjukkan bahwa self-efficacy siswa yang diajar dengan pendekatan metakognitif lebih baik dari pada pendekatan saintifik dilihat dari keseluruhan indikator maupun perindiikator yang ada dalam self-efficacy.

Dari hasil pengolahan data sebelumnya didapat kesimpulan bahawa self-efficacy siswa yang diajar memakai pendekatan metakognitif lebih baik dibandingkan pendekatan saintifik. Hal ini sejalan dengan penelitian I. J. Putri (2013). Fitri (2017) menyimpulkan bahwa self-efficacy yang dalam proses pembelajarannya memanfaatkan kegunaan dari pendekatan inovatif lebih baik dari pendekatan biasa. Putri meneliti pada siswa SD dengan menggunakan pendekatan realistik sedangkan Fitri meneliti pada siswa SMP dengan menggunakn pendekatan Aptitude Treatment Interaction. Adapun penyebab self-efficacy siswa yang pembelajarannya menggunakan pendekatan 
metakognitif lebih baik dari pendekatan saintifik adalah sebagai berikut:

Pada langkah pemodelan dalam metakognitif, pada langkah ini siswa melihat model yaitu seorang guru selama proses pembelajaran memberikan contoh dan teladan kepada siswa, dengan cara seperti ini siswa dapat memahami contoh yang diberikan guru, sehingga diharapkan siswa dapat menunjukan kemampuan berpikir metakognitifnya, hal ini sejalan dengan indikator vicarious experience yang merupakan cara seseorang belajar dari diri sendiri ataupun orang lain. Untuk mendapatkan pengalaman ini, seseorang akan menjadikan orang lain sebagai panutan bagi dirinya sendiri, dan kemudian akan ditiru dan diikuti (Setiadi, 2010).

Pada langkah kedua yaitu metacognitive scaffolding, pada kegiatan ini guru berusaha menghubungkan antara apa yang dapat dilakukan oleh siswa dengan cara sendiri dengan aktivitas yang perlu mendapat bantuan dari teman lainnya, kemudian dengan scaffolding guru memberikan pertanyaan atau mengajukan masalah yang mendorong siswa mengembangkan kemampuan awal siswa. Dengan demikian melalui scaffolding guru dapat membantu siswa mengubah tugas yang bersifat kompleks atau sukar menjadi lebih mudah untuk diselelsaikan dan diatur sendiri oleh siswa. Hal ini sejalan dengan indikator mastery experience adalah pengalaman otentik yang diperoleh seseorang dengan jalan merefleksikan hal-hal yang membuatnya gagal atau sukses. Bandura (1997) memaparkan berbagai faktor yang memengaruhi pengalaman nyata yaitu (1) meragukan kemampuan sendiri, (2) menerima dan menghadapi kesulitan, (3) cara memperoleh kemampuan, (4) pengaruh dari pihak lain, (5) metode, (6) waktu untuk menghadapi kesuksesan dan kegagalan, (7) cara individu mengolah pengalaman pribadinya termasuk proses kemampuan kognitif.

Pada langkah ketiga yaitu diskusi baik secara berpasangan, dalam kelompok kecil, atau dalam diskusi kelas. Menurut (Vygotsky, 1987) bahwa belajar bermakna akan berlangsung dalam suasana sosial. Ketika siswa saling berinteraksi dengan sesama teman, mereka saling sumbang informasi dan saran kepada anggota kelompok lainnya, Dengan diskusi ini mendorong siswa dapat mengatasi konflik yang muncul selama diskusi dan mereka mengkonstruk pengetahuan baru yang lebih sesuai dengan pengalaman belajar yang telah dilakukan. Hal ini sejalan dengan indikator persuasi verbal dan pengaruh sosial terkait dengan yang lainnya yaitu umpan balik yang disampaikan oleh individu yang lain berdasarkan apa yang diri pridadi lakukan, baik negatif maupun positif (Setiadi, 2010).

Pada langkah keempat, yaitu penulisan metacognitive journal, pada langkah ini siswa dituntut untuk menuliskan kembali langkahlangkah yang telah dilakukan atau merefleksi segala kegiatan atau tingkah laku selama pembelajaran berlangsung, hal ini sesuai dengan indikator Physiological and affective states yaitu aspek psikologi atau emosi. Bandura (Setiadi, 2010) mengatakan bahwa psikologi berkaitan dengan tingkah laku, dimana tingkat emosi mempengaruhi ia bertingkah baik atau buruk. Dengan hal itu, bisa ditarik kesimpulan bahwa langkahlangkah pada pembelajaran metakognitif sejalan dengan indikator yang ada pada selfefficacy.

\section{KESIMPULAN}

Dari hasil studi yang sudah dipaparkan, maka kesimpulan yang didapat adalah sebagi berikut. 
Penerapan pendekatan metakognitif terhadap self-efficacy siswa SMP ditinjau dari kemampuan awal siswa

a. Dilihat dari keseluruhan maupun Tingkat Kemampuan Awal Siswa dapat diketahui Self-efficacy matematis siswa dengan pendekatan metakognitif lebih baik daripada pendekatan saintifik.

b. Tidak adanya hubungan antara Tingkat Kemampuan Awal Siswa (TKAS) dan pendekatan pembelajaran terhadap SelfEfficacy siswa.

\section{REFERENSI}

Adni, D. N., Nurfauziah, P., \& Rohaeti, E. E. (2018). Analisis kemampuan koneksi matematis siswa SMP ditinjau dari self efficacy siswa. JPMI-Jurnal Pembelajaran Matematika Inovatif, 1(5), 957-964.

Aisyah. (2008). Pengaruh self efficacy, kecerdasan emosional, keinovatifan, komitmen organisasi terhadap kinerja pejabat eselon III Pemda Kota Palembang. Jakarta: Universitas Negeri Jakarta.

Alifia, N. N., \& Rakhmawati, I. A. (2018). Kajian kemampuan self-efficacy matematis siswa dalam pemecahan masalah matematika. Jurnal Elektronik Pembelajaran Matematika, 5(1), 44-54.

Aminah, M., Kusuma, Y. S., Suryadi, D., \& Sumarmo, U. (2018). Enhancing students' mathematical logical thinking ability and self regulated learning by using metacognitive teaching- learning. International Journal of Instruction, 11(3).

Armiati. (2011). Peningkatan kemampuan penalaran matematis, komunikasi matematis, dan kecerdasan emosional mahasiswa melalui pembelajaran berbasis masalah. UPI Bandung.

Bandura, A. (1997). Self-efficacy: the exercise of control. Macmillan.

Bandura, A., \& Ramachaudran, V. S. (1994). Encyclopedia of human behavior. New
York: Academic Press, 4, 71-81.

Fitri, I. (2017). Self Efficacy terhadap matematika melalui pendekatan aptitude treatment interaction. JRPM (Jurnal Review Pembelajaran Matematika), 2(2), 167-175.

Hendriana, H., Rohaeti, E. E., \& Sumarmo, U. (2017). Hard skills dan soft skills matematik siswa (I). Bandung: Refika Aditama.

Herawaty, D. (2013). Pengaruh kecerdasan emosional, partisipasi guru dalam forum ilmiah, keyakinan diri (self efficacy), dan motivasi kerja terhadap kinerja guru matematika (studi kausal di SMP Negeri se-Provinsi Bengkulu). Disertasi Doktor: Universitas Negeri Jakarta.

Juhrani, Suyitno, H., \& Khumaedi. (2017). Analisis kemampuan komunikasi matematis berdasarkan self-efficacy siswa pada model pembelajaran mea. Unnes Journal of Mathematics Education Research UJMER, 6(2), 251-258.

Jumroh, J., Mulbasari, A. S., \& Fitriasari, P. (2018). Self-efficacy siswa dalam pembelajaran matematika dengan strategi inquiry based learning di kelas VII SMP Palembang. Jurnal Pendidikan Matematika RAFA, 4(1), 29-42.

Mawaddah, N. E., \& Suyitno, H. (2015). Model pembelajaran discovery learning dengan pendekatan metakognitif untuk meningkatkan metakognisi dan kemampuan berpikir kreatif matematis. Unnes Journal of Mathematics Education Research, 4(1).

Nindiasari, H., Kusumah, Y. S., Sumarmo, U., \& Sabandar, Y. (2014). Pendekatan metakognitif untuk meningkatkan kemampuan berpikir reflektif matematis siswa SMA. Edusentris Journal of Education and Teaching, 1(1), 80-90.

Noordyana, M. A. (2016). Meningkatkan 
kemampuan berpikir kritis matematis siswa melalui pendekatan metacognitive instruction. Mosharafa Journal, 5(2), 120 127.

https://doi.org/https://doi.org/10.3929/ethz -b-000238666

Putri, I. J. (2013). Pengaruh pendekatan realistic mathematics education (rme) untuk meningkatkan kemampuan komunikasi matematis siswa dalam materi pecahan (penelitian eksperimen pada siswa kelas IV SDN 2 Waled Kota dan SDN 2 Waled Desa Kecamatan Waled Kabupaten Cirebon). Universitas Pendidikan Indonesia.

Putri, R. I., \& Santosa, R. H. (2015). Keefektifan strategi REACT ditinjau dari prestasi belajar, kemampuan penyelesaian masalah, koneksi matematis, self-efficacy. Jurnal Riset Pendidikan Matematika, 2(2), 262-272.

Riduwan, M. B. A. (2010). Metode dan teknik menyusun tesis. Bandung: Alfabeta.
Ruseffendi, E. T. (2010). Dasar-dasar penelitian pendidikan dan bidang noneksakta lainnya. (First). Bandung: Tarsito.

Setiadi, R. (2010). Self-efficacy in indonesian literarcy teaching context: a theoretical and empirical perspective. Rizqi Press.

Sukoco, H., \& Mahmudi, A. (2016). Pengaruh pendekatan brain-based learning terhadap kemampuan komunikasi matematis dan self-efficacy siswa SMA. PYTHAGORAS: Jurnal Pendidikan Matematika, 11(1), 1124.

Vygotsky, L. S. (1987). The collected works of LS Vygotsky: the fundamentals of defectology (Vol. 2). Springer Science \& Business Media.

Warsito, H. (2012). Hubungan antara selfefficacy dengan penyesuaian akademik dan prestasi akademik (Studi pada mahasiswa FIP Universitas Negeri Surabaya). Pedagogi: Jurnal Ilmu Pendidikan, 9(1), 29-47. 